\title{
Oscillations of sub-membrane ATP in glucose-stimulated beta cells depend on negative feedback from $\mathrm{Ca}^{2+}$
}

\author{
J. Li • H. Y. Shuai • E. Gylfe • A. Tengholm
}

Received: 23 November 2012 / Accepted: 4 March 2013 /Published online: 28 March 2013

(C) The Author(s) 2013. This article is published with open access at Springerlink.com

\begin{abstract}
Aims/hypothesis ATP links changes in glucose metabolism to electrical activity, $\mathrm{Ca}^{2+}$ signalling and insulin secretion in pancreatic beta cells. There is evidence that beta cell metabolism oscillates, but little is known about ATP dynamics at the plasma membrane, where regulation of ion channels and exocytosis occur.

Methods The sub-plasma-membrane ATP concentration $\left([\mathrm{ATP}]_{\mathrm{pm}}\right)$ was recorded in beta cells in intact mouse and human islets using total internal reflection microscopy and the fluorescent reporter Perceval.

Results Glucose dose-dependently increased $[\mathrm{ATP}]_{\mathrm{pm}}$ with half-maximal and maximal effects at 5.2 and $9 \mathrm{mmol} / \mathrm{l}$, respectively. Additional elevations of glucose to 11 to $20 \mathrm{mmol} / 1$ promoted pronounced $[\mathrm{ATP}]_{\mathrm{pm}}$ oscillations that were synchronised between neighbouring beta cells. $[\mathrm{ATP}]_{\mathrm{pm}}$ increased further and the oscillations disappeared when voltagedependent $\mathrm{Ca}^{2+}$ influx was prevented. In contrast, $\mathrm{K}^{+}$depolarisation induced prompt lowering of $[\mathrm{ATP}]_{\mathrm{pm}}$. Simultaneous recordings of $[\mathrm{ATP}]_{\mathrm{pm}}$ and the sub-plasma-membrane $\mathrm{Ca}^{2+}$ concentration $\left(\left[\mathrm{Ca}^{2+}\right]_{\mathrm{pm}}\right)$ during the early glucoseinduced response revealed that the initial $[\mathrm{ATP}]_{\mathrm{pm}}$ elevation preceded, and was temporarily interrupted by the rise of $\left[\mathrm{Ca}^{2+}\right]_{\mathrm{pm}}$. During subsequent glucose-induced oscillations, the increases of $\left[\mathrm{Ca}^{2+}\right]_{\mathrm{pm}}$ correlated with lowering of $[\mathrm{ATP}]_{\mathrm{pm}}$. Conclusions/interpretation In beta cells, glucose promotes pronounced oscillations of $[\mathrm{ATP}]_{\mathrm{pm}}$, which depend on negative feedback from $\mathrm{Ca}^{2+}$. The bidirectional interplay between these messengers in the sub-membrane space generates the metabolic and ionic oscillations that underlie pulsatile insulin secretion.
\end{abstract}

Electronic supplementary material The online version of this article (doi:10.1007/s00125-013-2894-0) contains peer-reviewed but unedited supplementary material, which is available to authorised users.

$\mathrm{J}$. Li $\cdot$ H. Y. Shuai $\cdot$ E. Gylfe $\cdot$ A. Tengholm $(\bowtie)$

Department of Medical Cell Biology, Biomedical Centre,

Uppsala University, Box 571, 75123 Uppsala, Sweden

e-mail: anders.tengholm@mcb.uu.se
Keywords ATP $\cdot \mathrm{Ca}^{2+} \cdot$ Human islets $\cdot$ Mouse islets . Oscillations $\cdot$ Pancreatic beta cell $\cdot$ Perceval $\cdot$ Plasma membrane

\begin{tabular}{|c|c|}
\hline \multicolumn{2}{|c|}{ Abbreviations } \\
\hline AM & Acetoxymethyl ester \\
\hline Ap5A & $\mathrm{P}^{1}, \mathrm{P}^{5}$-di(adenosine-5')-pentaphosphate \\
\hline$[\mathrm{ATP}]_{\mathrm{pm}}$ & Sub-plasma membrane ATP concentration \\
\hline BCECF & $2^{\prime}, 7^{\prime}$-Bis(2-carboxyethyl)-5(6)-carboxyfluorescein \\
\hline$\left[\mathrm{Ca}^{2+}\right]_{\mathrm{i}}$ & Cytoplasmic $\mathrm{Ca}^{2+}$ concentration \\
\hline$\left[\mathrm{Ca}^{2+}\right]_{\mathrm{pm}}$ & Sub-plasma membrane $\mathrm{Ca}^{2+}$ concentration \\
\hline EMCCD & Electron-multiplying charge-coupled device \\
\hline FCCP & $\begin{array}{l}\text { Carbonyl cyanide 4-(trifluoromethoxy) } \\
\text { phenylhydrazone }\end{array}$ \\
\hline $\mathrm{F} / \mathrm{F}_{0}$ & $\begin{array}{l}\text { Fluorescence in relation to initial fluorescence } \\
\text { after subtraction of background }\end{array}$ \\
\hline $\mathrm{K}_{\text {ATP }}$ & ATP-sensitive $\mathrm{K}^{+}$ \\
\hline TIRF & Total internal reflection fluorescence \\
\hline
\end{tabular}

\section{Introduction}

Glucose metabolism is central to the control of insulin secretion from pancreatic beta cells. The sugar enters the beta cell via GLUT transporters and is subsequently metabolised by glycolysis and mitochondrial oxidation [1,2]. The resulting increase of the intracellular ATP:ADP ratio closes ATPsensitive $\mathrm{K}^{+}\left(\mathrm{K}_{\mathrm{ATP}}\right)$ channels, causing plasma membrane depolarisation and influx of $\mathrm{Ca}^{2+}$ through voltage-gated channels. A rise of the cytoplasmic $\mathrm{Ca}^{2+}$ concentration $\left(\left[\mathrm{Ca}^{2+}\right]_{\mathrm{i}}\right)$ triggers exocytosis of insulin secretory granules [3]. ATP, as well as other metabolically derived factors, also serves to amplify insulin secretion by acting at sites distal to the elevation of $\left[\mathrm{Ca}^{2+}\right]_{\mathrm{i}}[4-6]$.

Insulin is released from beta cells in a pulsatile fashion with a periodicity of about 2 to $5 \mathrm{~min}$. The pulses involve oscillations of membrane potential and $\left[\mathrm{Ca}^{2+}\right]_{\mathrm{i}}[7,8]$, but 
other factors, including cAMP, have also been found to oscillate with a similar frequency [9-11]. One main hypothesis is that oscillations in metabolism drive changes in membrane potential via cyclic closure of $\mathrm{K}_{\mathrm{ATP}}$ channels. There is ample evidence for the presence of oscillations in beta cell metabolism. The first indication came from the observation that oxygen consumption oscillates in glucose-stimulated mouse islets [12]. This finding was subsequently confirmed with refined techniques $[13,14]$, and simultaneous measurements of $\mathrm{O}_{2}$ partial pressure and $\left[\mathrm{Ca}^{2+}\right]_{i}$ have shown coordinated oscillations with peaks of $\left[\mathrm{Ca}^{2+}\right]_{\mathrm{i}}$ coinciding with increases in oxygen consumption $[15,16]$. Moreover, the release of lactate [17], the intracellular concentration of NAD(P)H [18] and mitochondrial membrane potential oscillate $[19,20]$ at a similar frequency to the other variables. However, direct evidence of ATP oscillations have been more difficult to obtain. The ATP:ADP ratio has been reported to oscillate for one to two periods in samples from an islet cell suspension synchronised by clonidine and high $\mathrm{Ca}^{2+}$ treatment [21]. Continuous measurements of cytoplasmic ATP have been performed in beta cells with luciferase [22-26], but the luminescence signal is very weak, making such measurements technically demanding, with results often based on averaging the signal from many cells. Nevertheless, combining such measurements with autocorrelation analysis and data fit to a sine wave did provide statistical evidence of ATP oscillations in subpopulations of single mouse and human beta cells [25].

$\mathrm{Ca}^{2+}$ influences cell metabolism by several mechanisms, and feedback from $\mathrm{Ca}^{2+}$ may contribute to metabolic oscillations. The elevation of $\left[\mathrm{Ca}^{2+}\right]_{\mathrm{i}}$ can be expected to increase ATP consumption by $\mathrm{Ca}^{2+}$ extrusion mechanisms [27]. Moreover, $\mathrm{Ca}^{2+}$ uptake into mitochondria results in depolarisation of the mitochondrial inner membrane and thereby a decreased driving force for ATP production [19, 20, 28]. However, $\mathrm{Ca}^{2+}$ also stimulates mitochondrial dehydrogenases to generate $\mathrm{NADH}$, which results in increased ATP production [29-33]. Therefore, the net effect of $\left[\mathrm{Ca}^{2+}\right]_{\mathrm{i}}$ on cytoplasmic ATP is unclear. In the present study we used total internal reflection fluorescence (TIRF) microscopy and the novel fluorescent ATP biosensor Perceval [34] to investigate ATP dynamics and the relationship to $\mathrm{Ca}^{2+}$ in the subplasma membrane space of beta cells, where the nucleotide controls membrane potential and insulin granule exocytosis.

\section{Methods}

Materials MgATP, NaADP, diazoxide, EGTA, HEPES, carbonyl cyanide 4-(trifluoromethoxy)phenylhydrazone (FCCP), $\mathrm{NaN}_{3}$, methoxyverapamil, $\mathrm{P}^{1}, \mathrm{P}^{5}$-di(adenosine-5')pentaphosphate (Ap5A) and oligomycin were from Sigma (St Louis, MO, USA). $\mathrm{NH}_{4} \mathrm{Cl}$ was obtained from Merck
(Darmstadt, Germany), and 2',7'-bis(2-carboxyethyl)-5(6)carboxyfluorescein (BCECF) and Fura red from Invitrogen (Carlsbad, CA, USA). The Perceval plasmid was a kind gift from G. Yellen (Harvard Medical School, Boston, MA, USA). Vector Biolabs (Philadelphia, PA, USA) created a Perceval-expressing adenovirus.

MIN6 beta cell culture and transfection MIN6 beta cells (passages 19-32) [35] were cultured in DMEM with $25 \mathrm{mmol} / \mathrm{l}$ glucose and supplemented with $15 \%$ (vol./vol.) fetal calf serum, $2 \mathrm{mmol} / \mathrm{l}$ L-glutamine, $50 \mu \mathrm{mol} / 12$ mercaptoethanol, $100 \mathrm{units} / \mathrm{ml}$ penicillin and $100 \mu \mathrm{g} / \mathrm{ml}$ streptomycin. The cultures were maintained at $37^{\circ} \mathrm{C}$ in a $5 \% \mathrm{CO}_{2}$ humidified air atmosphere. Cells were seeded on polylysine-coated $25 \mathrm{~mm}$ coverslips. For each coverslip, 0.2 million cells were suspended in Optimem I medium (Invitrogen) containing $0.5 \mu$ l Lipofectamine 2000 (Invitrogen) and 0.2 to $0.4 \mu \mathrm{g}$ plasmid DNA, and placed on to the centre of the coverslip. After 3 to $4 \mathrm{~h}$, when the cells were firmly attached, the transfection was interrupted by adding $3 \mathrm{ml}$ complete cell culture medium. Cells were maintained in this medium for 24 to $48 \mathrm{~h}$.

Islet isolation and virus infection All procedures for animal handling, islet isolation and use of human islets were approved by local animal and human ethics committees. Most experiments were performed with islets isolated with collagenase from the pancreases of 5- to 7-month-old female C57Bl/6J mice (Taconic, Ry, Denmark). The main findings were also reproduced with islets from 6-week-old mice of both sexes. The islets were transferred to RPMI 1640 culture medium containing $5.5 \mathrm{mmol} / 1$ glucose and supplemented with $10 \%$ (vol./vol.) fetal calf serum, 100 units $/ \mathrm{ml}$ penicillin and $100 \mu \mathrm{g} / \mathrm{ml}$ streptomycin for culture lasting 1 to 2 days at $37^{\circ} \mathrm{C}$ in a $5 \% \mathrm{CO}_{2}$ humidified air atmosphere. Human islets from two normoglycaemic cadaveric donors (one man aged 60 years, BMI 24.2; one woman aged 70 years, BMI 31.1) were provided by the Nordic Network for Clinical Islet Transplantation. The islets were kept for 24 to $72 \mathrm{~h}$ at $37^{\circ} \mathrm{C}$ in an atmosphere of $5 \% \mathrm{CO}_{2}$ in CMRL 1066 culture medium (Mediatech, Herndon, VA, USA) containing $5.6 \mathrm{mmol} / \mathrm{l}$ glucose and supplemented with $10 \mathrm{mmol} / \mathrm{l}$ nicotinamide, $10 \mathrm{mmol} / 1 \mathrm{HEPES}, 0.25 \mu \mathrm{g} / \mathrm{ml}$ fungizone, $50 \mu \mathrm{g} / \mathrm{ml}$ gentamycin, $2 \mathrm{mmol} / \mathrm{l}$ glutamine, $10 \mu \mathrm{g} / \mathrm{ml}$ ciprofloxacin and $10 \%$ (vol./vol.) heat-inactivated human serum. The islets were infected for 1 to $2 \mathrm{~h}$ with Perceval adenovirus at a concentration of 20 plaque-forming units/cell in medium containing $2 \%$ (vol./vol.) serum; this was followed by washing with normal RPMI 1640 medium and further culture for 16 to $20 \mathrm{~h}$ before use.

Measurements of intracellular ATP, $\mathrm{Ca}^{2+}$ and $\mathrm{pH}$ MIN6 beta cells on coverslips were preincubated for 30 to 
$60 \mathrm{~min}$ at $37^{\circ} \mathrm{C}$ in experimental buffer containing (in mmol/l): $\mathrm{NaCl} 125, \mathrm{KCl} 4.8, \mathrm{MgCl}_{2}$ 1.2, $\mathrm{CaCl}_{2}$ 1.3, HEPES 25 and glucose 3.0 , with $\mathrm{pH}$ set at 7.40 with $\mathrm{NaOH}$. Cytoplasmic ATP measurements were made in cells expressing Perceval. For measurements of cytoplasmic $\mathrm{pH}$ in untransfected cells, $5 \mu \mathrm{mol} / \mathrm{l}$ of the $\mathrm{pH}$ indicator BCECF acetoxymethyl ester (AM) was present during preincubation. The coverslips with the attached cells were then used as exchangeable bottoms of an open $50 \mu \mathrm{l}$ chamber and mounted on the stage of a microscope (Eclipse TE2000; Nikon, Kanagawa, Japan) equipped with a spinning disk confocal unit (Yokogawa CSU-10; Andor Technology, Belfast, Northern Ireland, UK) and a $60 \times, 1.40-N A$ objective. Perceval was excited with laser light at $488 \mathrm{~nm}$ and BCECF with 514 and $442 \mathrm{~nm}$. Emission was detected at 527/27 nm (centre wavelength/half-bandwidth) for Perceval, and at 485/25 nm and 560/40 nm for BCECF. For detection we used interference filters (Semrock, Rochester, NY, USA) mounted in a filter wheel (Sutter Instruments, Novato, CA, USA) and an electron-multiplying charge-coupled device (EMCCD) camera (DU-888E; Andor) controlled by MetaFluor software (Molecular Devices, Downingtown, PA, USA).

Intact pancreatic islets were preincubated for $30 \mathrm{~min}$ in experimental buffer before TIRF imaging experiments. The sub-plasma membrane ATP concentration ([ATP $]_{\mathrm{pm}}$ ) was measured in superficially located islet cells expressing Perceval. For measurements of $\mathrm{pH}$ or sub-plasma-membrane $\mathrm{Ca}^{2+}$ concentration $\left(\left[\mathrm{Ca}^{2+}\right]_{\mathrm{pm}}\right)$, the preincubation buffer was supplemented with $1 \mu \mathrm{mol} / 1 \mathrm{BCECF}-\mathrm{AM}$ or $5 \mu \mathrm{mol} / 1$ Fura red-AM, respectively. The islets were then placed on a poly-Llysine-coated coverslip in the superfusion chamber on the microscope stage. Measurements began after 5 to $10 \mathrm{~min}$ when the superficial islet cells had formed large contact areas with the coverslip. The microscope (Eclipse Ti; Nikon) was equipped with a TIRF illuminator and a $60 \times, 1.45$-NA objective (Nikon). An argon laser provided 488, 458 and $514 \mathrm{~nm}$ light for excitation of Perceval, Fura red and BCECF. An EMCCD camera (DU-897; Andor) controlled by MetaFluor software (Molecular Devices) was used for fluorescence detection. Emission wavelengths were selected as in the confocal system. Confocal and TIRF imaging were performed at $37^{\circ} \mathrm{C}$, with a medium superfusion rate of 0.12 to $0.20 \mathrm{ml} / \mathrm{min}$ and with images or image pairs acquired every 5 to $6 \mathrm{~s}$.

Plasma membrane permeabilisation Some experiments were performed after permeabilisation of the beta cell plasma membrane with Staphylococcus aureus $\alpha$-toxin (PhPlate, Stockholm, Sweden), which creates 1- to 2-nm pores permeable to ions, nucleotides and molecules smaller than $\sim 3 \mathrm{kDa}$ [36]. The cells were superfused with an intracellular-like medium containing $140 \mathrm{mmol} / \mathrm{l} \mathrm{KCl}$, $6 \mathrm{mmol} / 1 \mathrm{NaCl}, 1 \mathrm{mmol} / \mathrm{l} \mathrm{MgCl}_{2}, 0.465 \mathrm{mmol} / 1 \mathrm{CaCl}_{2}$,
$2 \mathrm{mmol} / 1$ EGTA and $12.5 \mathrm{mmol} / 1 \mathrm{HEPES}$, with $\mathrm{pH}$ adjusted to 7.00 with $\mathrm{KOH}$. The perfusion was temporarily interrupted and $5 \mu \mathrm{l} \alpha$-toxin $(0.46 \mathrm{mg} / \mathrm{ml})$ added directly to the $50 \mu \mathrm{l}$ chamber. After 2 to $5 \mathrm{~min}$, the cells were washed and exposed to MgATP in the $1-10 \mathrm{mmol} / \mathrm{l}$ range. To test the influence of ADP, 0.1 or $1 \mathrm{mmol} / 1 \mathrm{NaADP}$ was added in some experiments. The free $\mathrm{Mg}^{2+}$ and $\mathrm{Ca}^{2+}$ concentrations were always maintained at $1 \mathrm{mmol} / \mathrm{l}$ and $100 \mathrm{nmol} / \mathrm{l}$, respectively.

Data analysis Image analysis was carried out using MetaFluor or Fiji (http://fiji.sc/wiki/index.php/Fiji) software. Fluorescence intensities are expressed as changes of fluorescence in relation to initial fluorescence after subtraction of background value $\left(\mathrm{F} / \mathrm{F}_{0}\right)$. BCECF was measured as the fluorescence ratio of $514: 442$ or $514: 458 \mathrm{~nm}$ excitation. Igor Pro (Wavemetrics, Lake Oswego, OR, USA) and Sigmaplot 12 (Systat Software, San José, CA, USA) software were used for curve fitting and the xcorr function in MATLAB (The Mathworks, Natick, MA, USA) for crosscorrelation analysis. Data are expressed as mean values \pm SEM. Statistical significance was evaluated using Student's $t$ test.

\section{Results}

Perceval detects millimolar concentrations of ATP The nucleotide-binding properties originally reported for Perceval [34] indicated that the probe would be unsuitable for measurements of ATP in the physiological concentration range. To investigate the ATP sensitivity of Perceval, MIN6 beta cells expressing the sensor were imaged with confocal microscopy. After introduction of an intracellularlike medium lacking ATP, the plasma membrane was permeabilised with $\alpha$-toxin, resulting in a $66 \pm 2 \%(n=15)$ decrease of Perceval fluorescence due to biosensor dilution by cell swelling and escape of ATP. As 1-10 mmol/1 MgATP was added to the intracellular-like medium, Perceval fluorescence increased in a concentration-dependent and reversible manner (Fig. 1a). The dose-response relationship was hyperbolic with half-maximal effect occurring at $2.2 \mathrm{mmol} / 1$ ATP (Fig. 1b).

Perceval has been reported to be sensitive to the ATP: ADP ratio rather than to ATP alone [34]. We therefore investigated the influence of ADP on Perceval fluorescence in permeabilised MIN6 beta cells. The addition of $1 \mathrm{mmol} / 1$ ADP alone induced a prompt fluorescence increase. This effect reflected, at least in part, the conversion of ADP to ATP via adenylate kinase, since an inhibitor of this enzyme, Ap5A, markedly reduced the effect of ADP. ATP (1 mmol/l) increased Perceval fluorescence in the presence of ADP and Ap5A, but changes of the ATP:ADP ratio from 1 to 10 by 
a

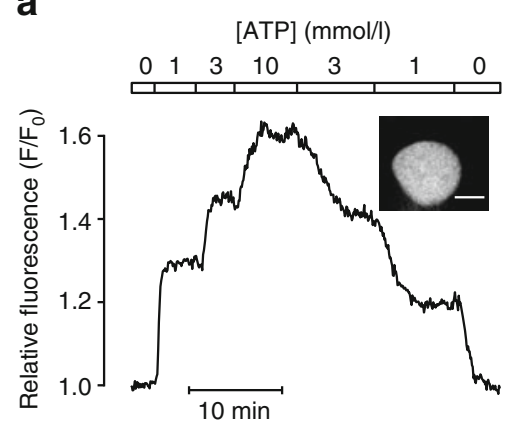

C

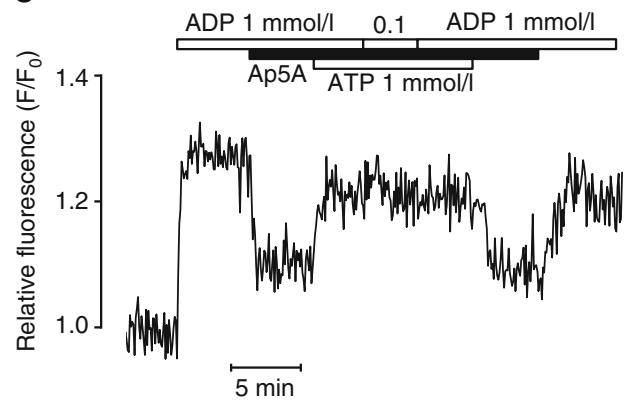

b

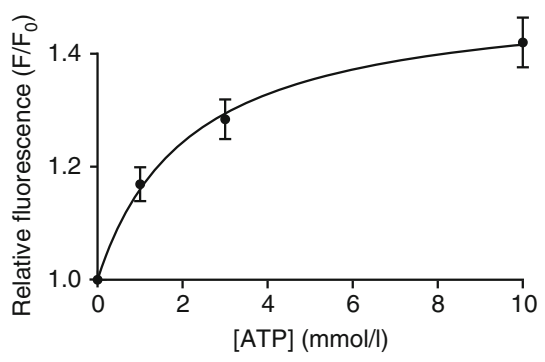

d

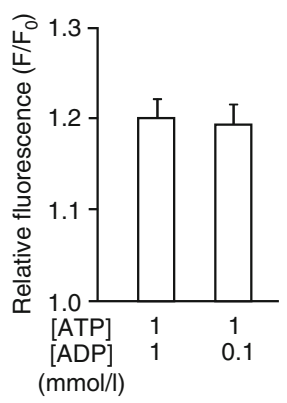

hyperbolic function with half-maximal effect at $2.2 \mathrm{mmol} / \mathrm{l}$ ATP $(n=21)$. (c) Influence of MgATP, NaADP and $200 \mu \mathrm{mol} / 1$ of the adenylate kinase inhibitor, Ap5A, on Perceval fluorescence in an individual $\alpha$-toxin-permeabilised MIN6 beta cell. (d) Mean \pm SEM for the average Perceval fluorescence during changes of the ADP concentration in a permeabilised MIN6 beta cell exposed to $1 \mathrm{mmol} / \mathrm{l}$ ATP and $200 \mu \mathrm{mol} / 1 \mathrm{Ap} 5 \mathrm{~A}$ as above (c) $(n=9)$

changes in intracellular $\mathrm{pH}$. MIN6 beta cells loaded with the $\mathrm{pH}$ indicator $\mathrm{BCECF}$ showed no change in cytoplasmic $\mathrm{pH}$ when stimulated with glucose, but a pronounced alkalinisation when stimulated by $10 \mathrm{mmol} / 1 \mathrm{NaN}_{3}$ and $5 \mu \mathrm{mol} / \mathrm{l}$ FCCP (electronic supplementary material [ESM] Fig. 1a). Alkalinisation increases Perceval fluorescence [34], so the ATP reduction caused by the mitochondrial toxins may therefore be underestimated. The cytoplasmic alkalinisation and acidification caused by addition and removal of $20 \mathrm{mmol} / \mathrm{l} \mathrm{NH} \mathrm{N}_{4} \mathrm{Cl}$, respectively, were associated with pronounced changes in Perceval fluorescence (ESM Fig. 1a). Although we confirmed the pH-sensitivity of Perceval, the fluorescence changes induced by glucose could not be attributed to variations in cytoplasmic $\mathrm{pH}$.

Glucose-induced $[A T P]_{p m}$ dynamics in primary mouse islet cells We next monitored $[\mathrm{ATP}]_{\mathrm{pm}}$ in primary islet cells using TIRF microscopy. With this approach, Perceval ATP sensitivity was similar to that in MIN6 beta cells with a halfmaximal fluorescence change at $2.6 \mathrm{mmol} / \mathrm{l}$ (data not shown). When islets were placed on a coverslip, cells in the islet periphery quickly adhered to the glass with large contact areas (Fig. 3a). In most cells, the elevation of glucose from 3 to 11 or $20 \mathrm{mmol} / \mathrm{l}$ induced a multiphasic 
a

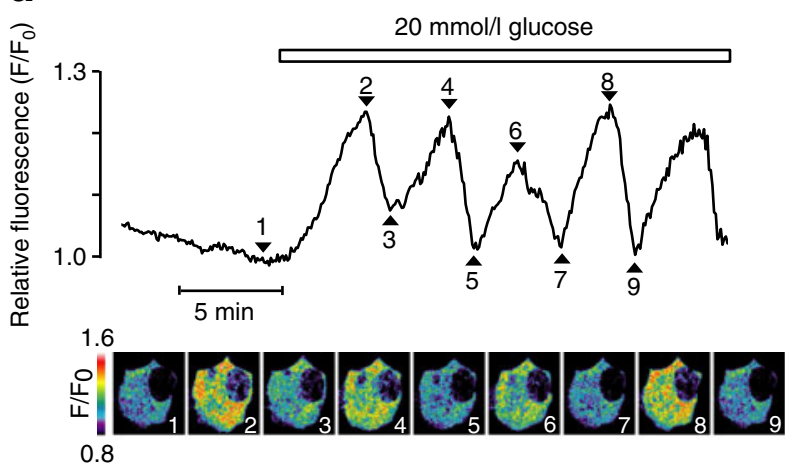

b

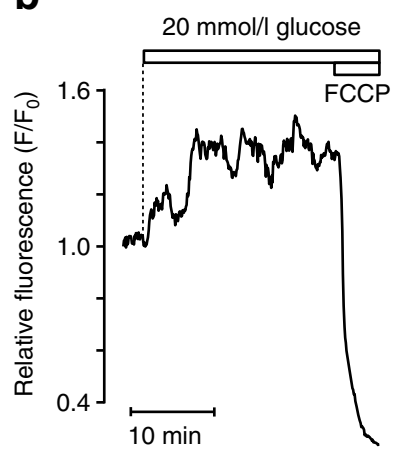

C

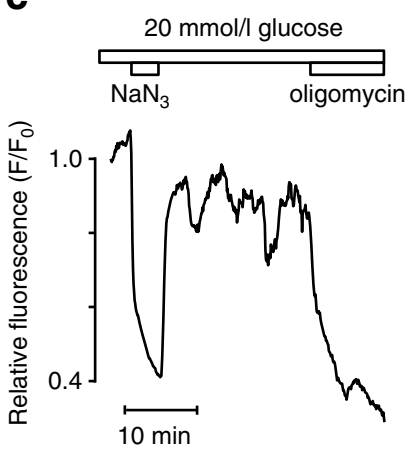

Fig. 2 Glucose induces ATP oscillations in single MIN6 beta cells. (a) Confocal microscopy recording of Perceval fluorescence from a single MIN6 beta cell during elevation of the glucose concentration from 3 to $20 \mathrm{mmol} / \mathrm{l}$. Relative fluorescence intensities are shown at the time points indicated by numbered arrowheads. Findings are representative of 69 cells. (b) Effects of the mitochondrial uncoupler FCCP $(5 \mu \mathrm{mol} / 1$; $n=18)$, and (c) of the cytochrome oxidase inhibitor $\mathrm{NaN}_{3}(5 \mathrm{mmol} / \mathrm{l})$ and the ATP synthase inhibitor oligomycin $(5 \mu \mathrm{g} / \mathrm{ml} ; n=8)$ on Perceval fluorescence in single MIN6 beta cells exposed to $20 \mathrm{mmol} / \mathrm{l}$ glucose

response, starting with a fluorescence increase, which was transiently interrupted after about $1 \mathrm{~min}$. The increase then continued for about $5 \mathrm{~min}$ and developed into regular oscillations superimposed on an elevated plateau and synchronised between neighbouring cells in the islet (Fig. 3b). The oscillations in Perceval fluorescence did not reflect changes in $\mathrm{pH}$. Accordingly, glucose had little effect on $\mathrm{pH}$ in BCECF-loaded islets, while alkalinisation with $\mathrm{NH}_{4} \mathrm{Cl}$ caused a dramatic rise of the BCECF and Perceval signals (ESM Fig. 1b). The glucose-induced increase and oscillations of Perceval fluorescence largely reflected the responses of beta cells, since $81 \%$ of the Perceval-expressing cells ( $n=186$ cells in eight islets) immunostained for insulin (not shown).

To investigate the glucose dependence of $[\mathrm{ATP}]_{\mathrm{pm}}$, the islets were exposed to small, stepwise increases of the glucose concentration in the 1 to $20 \mathrm{mmol} / 1$ range. As shown in Fig. 3c, d, Perceval fluorescence increased in response to glucose elevations from 1 to $3 \mathrm{mmol} / \mathrm{l}$, with additional concentration-dependent increases occurring at up to $9 \mathrm{mmol} / \mathrm{l}$ glucose. The dose-response relationship was sigmoidal with half-maximal effect at $5.2 \pm 0.2 \mathrm{mmol} / 1$ glucose (Fig. 3d). There was no significant further increase of time-average fluorescence at 11 or $20 \mathrm{mmol} / 1$ glucose. However, whereas very few cells showed Perceval fluorescence oscillations in the presence of 1 to $9 \mathrm{mmol} / 1$ glucose, $60 \%$ oscillated at $11 \mathrm{mmol} / 1$ and virtually all cells $(98 \%)$ at $20 \mathrm{mmol} / 1$ glucose (Fig. 3e). Whereas a slight increase in the amplitude of oscillations at 20 compared with $11 \mathrm{mmol} / \mathrm{l}$ glucose could be ascribed to time rather than the concentration difference (not shown), a significant decrease of the half-width of each oscillation was observed at the higher glucose concentration (Fig. 3f).

Influence of $\mathrm{Ca}^{2+}$ on $[A T P]_{p m}$ To clarify the interplay between $[\mathrm{ATP}]_{\mathrm{pm}}$ and $\left[\mathrm{Ca}^{2+}\right]_{\mathrm{pm}}$, the two messengers were simultaneously recorded with TIRF microscopy. A rise of $\left[\mathrm{Ca}^{2+}\right]_{\text {pm }}$ by membrane depolarisation at $30 \mathrm{mmol} / 1 \mathrm{KCl}$ was accompanied by a decrease of Perceval fluorescence to $73 \pm$ $10 \%$ of baseline, which was reversed upon restoration of the $\mathrm{KCl}$ concentration (Fig. 4a) or by the addition of $50 \mu \mathrm{mol} / 1$ of the L-type calcium channel blocker methoxyverapamil (Fig. 4b). $\mathrm{KCl}$ depolarisation also caused lowering of Perceval fluorescence in the presence of $20 \mathrm{mmol} / \mathrm{l}$ glucose (Fig. 4c). Control experiments showed that $\mathrm{KCl}$-induced fluorescence changes were not secondary to changes in intracellular pH (ESM Fig. 1c).

When cells were stimulated with $20 \mathrm{mmol} / 1$ glucose after hyperpolarisation with the $\mathrm{K}_{\mathrm{ATP}}$ channel activator, diazoxide $(250 \mu \mathrm{mol} / \mathrm{l})$, or in the absence of extracellular $\mathrm{Ca}^{2+}\left(\mathrm{Ca}^{2+}\right.$ omission with addition of $2 \mathrm{mmol} / 1$ EGTA), we observed an uninterrupted increase of Perceval fluorescence to a plateau without oscillations (Fig. 4d, e). The plateau level was much higher than the level at the temporary $\mathrm{Ca}^{2+}$. induced interruption of the initial elevation in controls (Fig 4f). In the absence of $\mathrm{Ca}^{2+}$ entry, a slight timedependent lowering of Perceval fluorescence occurred, reaching statistical significance after $20 \mathrm{~min}$ (Fig. 4f). The removal of diazoxide or reintroduction of $\mathrm{Ca}^{2+}$ resulted in a rapid decrease of fluorescence and the appearance of oscillations, indicating that elevation of $\left[\mathrm{Ca}^{2+}\right]_{\mathrm{pm}}$ is a prerequisite for the Perceval oscillations. By analogy, the inhibition of voltage-dependent $\mathrm{Ca}^{2+}$ influx by methoxyverapamil (Fig. 4g) or diazoxide hyperpolarisation (not shown) interrupted established oscillations that had been induced by glucose, and significantly elevated Perceval fluorescence. Neither diazoxide nor methoxyverapamil affected pH under such conditions (ESM Fig. 1d). Human islet cells responded in ways that were essentially similar to those of mouse beta cells. Glucose thus induced a pronounced rise, with oscillations, of Perceval fluorescence, which were lost when diazoxide caused an additional elevation of the signal and subsequent $\mathrm{KCl}$ depolarisation resulted in a marked decrease of Perceval intensity (Fig. 4h). 
a

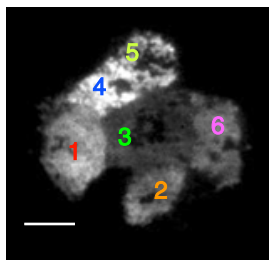

b

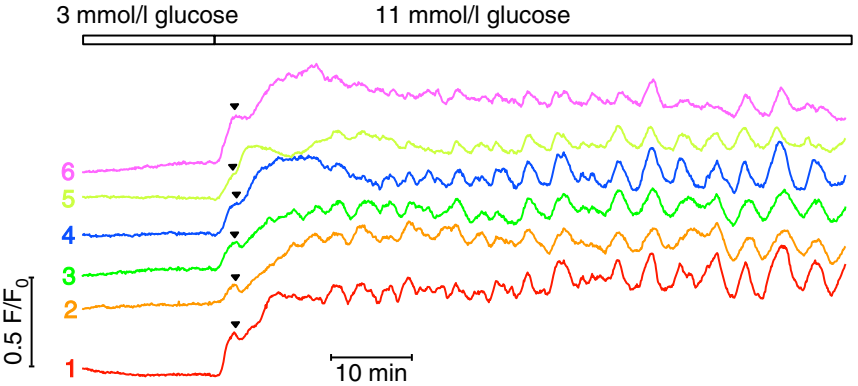

C

[Glucose] (mmol/l)

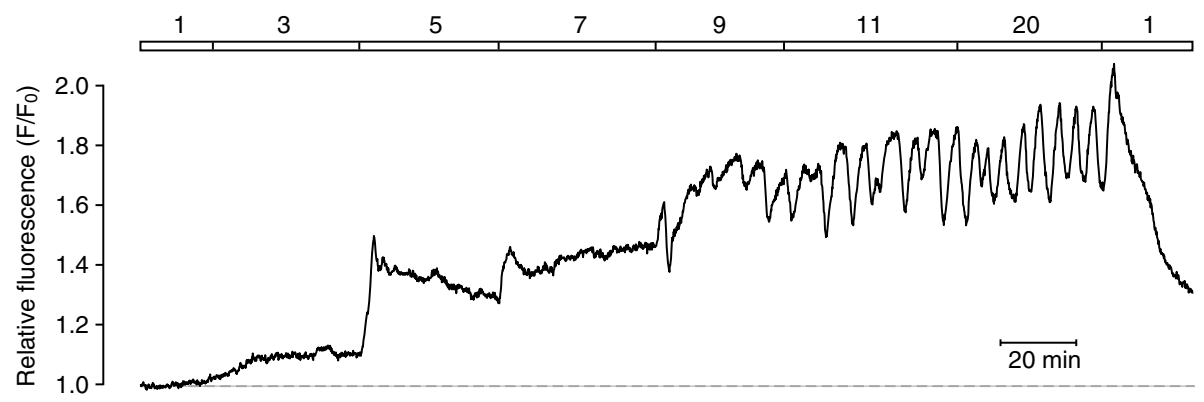

d

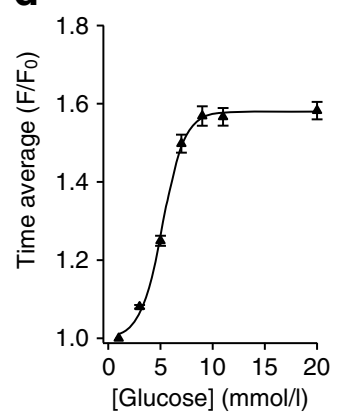

e

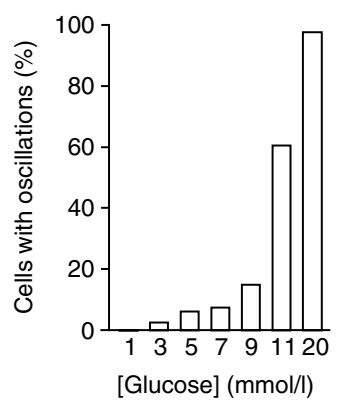

f

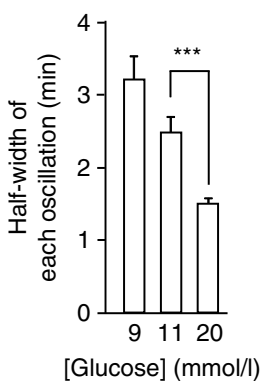

Fig. 3 Glucose-induced $[\mathrm{ATP}]_{\mathrm{pm}}$ oscillations in beta cells in intact pancreatic islets. (a) TIRF microscopy image of Perceval-expressing cells in an intact mouse pancreatic islet; scale bar $10 \mu \mathrm{m}$. (b) TIRF intensity recording showing synchronised elevations and oscillations of Perceval fluorescence during glucose stimulation of the six cells indicated in (a). A transient interruption of the initial glucose-induced increase of Perceval fluorescence occurred consistently; see arrowheads. (c) TIRF intensity recording from a single cell in an intact islet exposed to increasing concentrations of glucose. (d) Time-average

Glucose triggers anti-parallel oscillations of $[A T P]_{p m}$ and $\left[\mathrm{Ca}^{2+}\right]_{p m}$ in beta cells To further investigate the relationship between $[\mathrm{ATP}]_{\mathrm{pm}}$ and $\left[\mathrm{Ca}^{2+}\right]_{\mathrm{pm}}$, we performed simultaneous recordings of the two messengers in islet beta cells during glucose stimulation. $[\mathrm{ATP}]_{\mathrm{pm}}$ and $\left[\mathrm{Ca}^{2+}\right]_{\mathrm{pm}}$ were low and stable in the presence of $3 \mathrm{mmol} / 1$ glucose. Elevation of the glucose concentration to $20 \mathrm{mmol} / \mathrm{l}$ induced an immediate increase of Perceval fluorescence, which coincided with an initial lowering of $\left[\mathrm{Ca}^{2+}\right]_{\mathrm{pm}}$. The subsequent elevation of $\left[\mathrm{Ca}^{2+}\right]_{\mathrm{pm}}$ was associated with a transient interruption of the increase in Perceval fluorescence. Oscillations appeared after 5 to $10 \mathrm{~min}$; during the oscillations each elevation of $\left[\mathrm{Ca}^{2+}\right]_{\mathrm{pm}}$
Perceval fluorescence as mean \pm SEM at different glucose concentrations for 72 cells from seven islets. The line is a sigmoidal fit to the seven data points. (e) Percentage of cells showing oscillations of Perceval intensity at different concentrations of glucose; $n=81$ cells from seven islets. (f) Mean \pm SEM of the half-width of each oscillation of Perceval fluorescence at different glucose concentrations; $n=24,35$ and 46 oscillations from nine cells in six islets exposed to 9,11 and $20 \mathrm{mmol} / 1$ glucose, respectively; ${ }^{* * *} p<0.001$ for difference between groups

was associated with a lowering of Perceval fluorescence (Fig. 5a). Cross-correlation analysis calculated from consecutive data segments of 150 image pairs revealed that the peaks of $\left[\mathrm{Ca}^{2+}\right]_{\mathrm{pm}}$ preceded the nadirs of $[\mathrm{ATP}]_{\mathrm{pm}}$ by $32 \pm 2 \mathrm{~s}$ with a correlation coefficient of $-0.91 \pm$ $0.01(p<0.001)$ (Fig. 5b).

\section{Discussion}

Cytoplasmic ATP plays a key role in pancreatic beta cell stimulus-secretion coupling [3], but at present there is little 
a

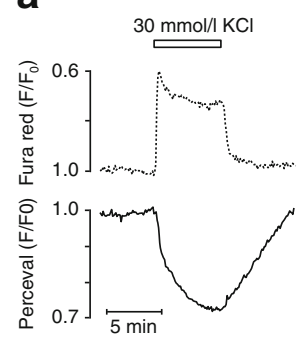

d

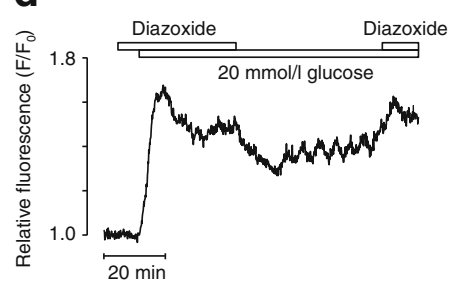

g

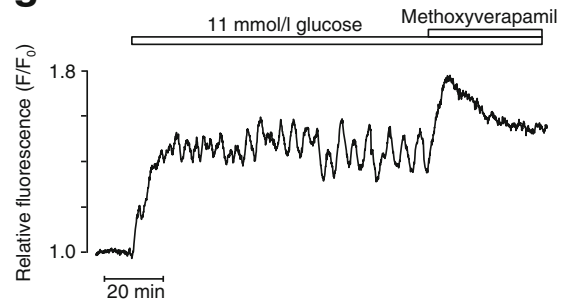

Fig. 4 Influence of $\mathrm{Ca}^{2+}$ on $[\mathrm{ATP}]_{\mathrm{pm}}$ in pancreatic islet cells. (a) Simultaneous TIRF recordings of $[\mathrm{ATP}]_{\mathrm{pm}}$ with Perceval (lower trace) and $\left[\mathrm{Ca}^{2+}\right]_{\mathrm{pm}}$ with Fura red (upper trace) in a single islet beta cell during membrane depolarisation with $30 \mathrm{mmol} / 1 \mathrm{KCl}$ in the presence of $3 \mathrm{mmol} / \mathrm{l}$ glucose. Traces are representative of 16 cells in three islets. (b) Effect of $50 \mu \mathrm{mol} / 1$ methoxyverapamil on $[\mathrm{ATP}]_{\mathrm{pm}}$ in an islet cell depolarised with $30 \mathrm{mmol} / 1 \mathrm{KCl} ; n=13$ cells in two islets. (c) TIRF recording of $[\mathrm{ATP}]_{\mathrm{pm}}$ during elevation of the glucose concentration from 3 to $20 \mathrm{mmol} / \mathrm{l}$, followed by further membrane depolarisation with $30 \mathrm{mmol} / 1 \mathrm{KCl} ; n=25$ cells in 32 islets. (d) $[\mathrm{ATP}]_{\mathrm{pm}}$ during elevation of the glucose concentration from 3 to $20 \mathrm{mmol} / 1$ in the presence of $250 \mu \mathrm{mol} / 1$ diazoxide ( $n=28$ cells in three islets) or (e) in $\mathrm{Ca}^{2+}$-deficient medium containing $2 \mathrm{mmol} / 1$ EGTA $(n=20$ cells in three

information about ATP dynamics. The lack of data largely reflects difficulties in monitoring ATP changes in single cells, which would be necessary to elucidate the temporal relationships with other messengers and insulin secretion. In the present study we used the fluorescent ATP-binding biosensor Perceval [34] to record $[\mathrm{ATP}]_{\mathrm{pm}}$ in glucosestimulated beta cells and clarify the interplay between $[\mathrm{ATP}]_{\mathrm{pm}}$ and $\left[\mathrm{Ca}^{2+}\right]_{\mathrm{pm}}$. Perceval was first described to have micromolar affinity for MgATP [34], which is not ideal for measurements of physiological ATP concentrations in mammalian cells. However, competition with ADP was suggested to make the reporter sensitive to the ATP:ADP ratio rather than absolute concentrations of the nucleotides. We have now found that Perceval expressed in intact cells responds instead to physiological ATP concentrations in the
C
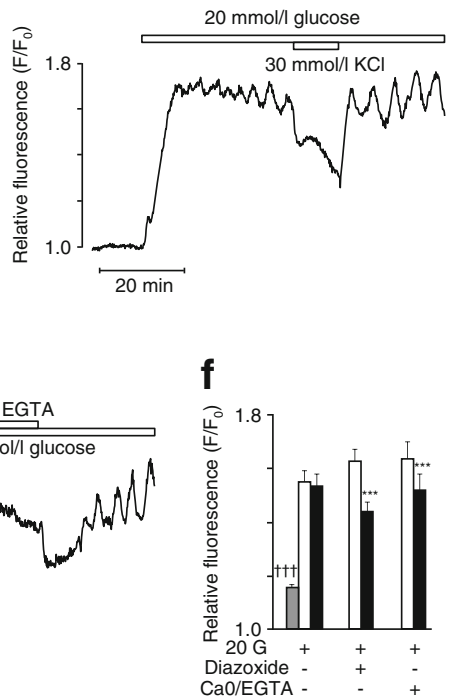

h

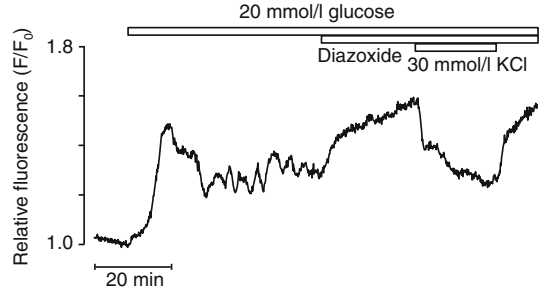

islets). (f) Mean \pm SEM of Perceval fluorescence levels at the time of temporary interruption of the initial rising phase (grey bar; only present in control cells), as well as during the following peak of the glucose response (white bars) and at $20 \mathrm{~min}$ after the peak (black bars). ${ }^{* * *} p<$ 0.001 for difference between first peak and 20 min level; ${ }^{\dagger \dagger} p<0.001$ for difference from first peak in all groups. (g) Effect of $50 \mu \mathrm{mol} / 1$ methoxyverapamil on glucose-induced oscillations of Perceval fluorescence; $n=41$ cells in three islets. (h) Effects of glucose elevation from 1 to $20 \mathrm{mmol} / 1$ and of subsequent additions of $250 \mu \mathrm{mol} / 1$ diazoxide and $30 \mathrm{mmol} / 1 \mathrm{KCl}$ on Perceval fluorescence in a single cell in an intact human islet; $n=10$ cells in two islets. $\mathrm{Ca} 0, \mathrm{Ca}^{2+}$-deficient medium

millimolar range (Fig. 1). Analysis of ADP sensitivity was complicated by the fact that beta cells contain adenylate kinase [37], which converts two molecules of ADP into ATP and AMP. However, after inhibition of such ATP production, we observed no effect of changes of the ATP:ADP ratio from 1 to 10 in the presence of $1 \mathrm{mmol} / 1 \mathrm{MgATP}$ (Fig. 1). Since the original report was based on in vitro experiments with purified proteins, we believe that the present in situ characterisation better reflects the physiological situation. We therefore conclude that Perceval is indeed sensitive to ATP in a physiologically relevant concentration range.

Since Perceval is pH-sensitive [34], care was taken to verify that the observed fluorescence changes were not caused by changes in intracellular $\mathrm{pH}$. In accordance with previous studies in insulinoma and islet cells [22-25, 33], 
a

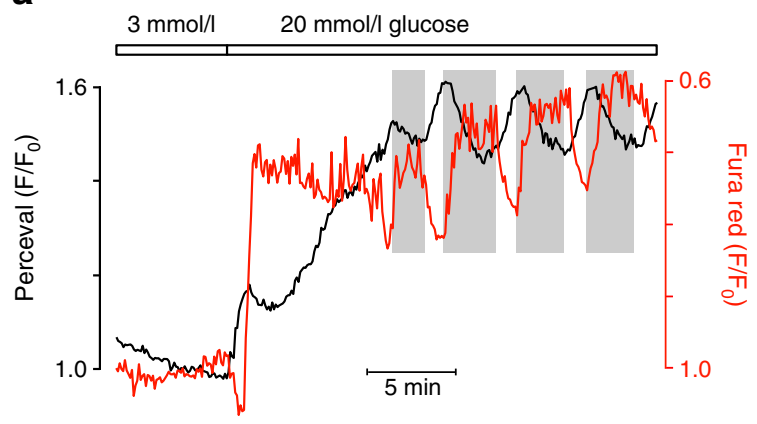

b

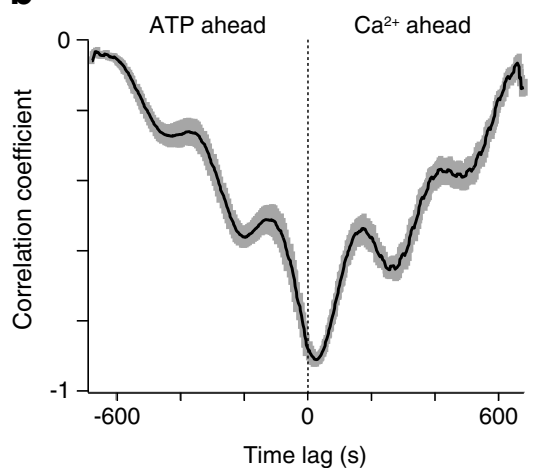

Fig. 5 Temporal relationship between changes of $[\mathrm{ATP}]_{\mathrm{pm}}$ and $\left[\mathrm{Ca}^{2+}\right]_{\mathrm{pm}}$. (a) Simultaneous TIRF recordings of $[\mathrm{ATP}]_{\mathrm{pm}}$ with Perceval (black trace) and $\left[\mathrm{Ca}^{2+}\right]_{\mathrm{pm}}$ with Fura red (red trace) in a single cell in an intact mouse pancreatic islet exposed to a one-step increase of the glucose concentration from 3 to $20 \mathrm{mmol} / \mathrm{l}$. Shaded areas indicate the rising phases of the $\left[\mathrm{Ca}^{2+}\right]_{\mathrm{pm}}$ oscillations, which coincide with reductions of Perceval fluorescence. (b) Cross-correlation analysis of the changes of $[\mathrm{ATP}]_{\mathrm{pm}}$ and $\left[\mathrm{Ca}^{2+}\right]_{\mathrm{pm}}$, calculated from consecutive data segments of 150 image pairs. The black line is an average correlogram (with SEM in grey) from 16 simultaneous recordings of Perceval and Fura red fluorescence in five islets. Cross-correlation was calculated for data segments corresponding to 3 to 3.5 oscillations. Apart from the major minimum close to time 0 , the cross-correlogram therefore shows additional minima at time lags corresponding to each multiple of an oscillation period

glucose was found to induce a concentration-dependent general increase of ATP in the cytoplasm of MIN6 beta cells (Fig. 2). We also found a marked ATP increase in the sub-plasma membrane space of glucose-stimulated primary mouse and human beta cells in intact islets of Langerhans (Figs 3 and 4). Since recordings did not allow the determination of absolute ATP concentration changes, it is difficult to directly compare ATP levels in the different subcellular compartments. However, consistent with previous observations in beta cells [24] and other cells [38], our confocal measurements did not reveal any apparent ATP gradient between the sub-membrane space and the bulk cytoplasm. Glucose concentrations $>9 \mathrm{mmol} / \mathrm{l}$ triggered robust $[\mathrm{ATP}]_{\mathrm{pm}}$ oscillations in beta cells, confirming previous evidence of metabolic oscillations in glucosestimulated beta cells [12-18, 25]. Some observations have indicated that metabolism also oscillates in the presence of sub-stimulatory glucose concentrations. For example, basal insulin secretion from isolated islets was found to be pulsatile when $\left[\mathrm{Ca}^{2+}\right]_{\mathrm{i}}$ was low and stable [39], and $\mathrm{K}_{\text {ATP }}$ channel conductance fluctuated under basal conditions with a frequency similar to that of slow metabolic oscillations [40]. However, in the present study only some cells showed ATP oscillations at glucose concentrations below $9 \mathrm{mmol} / \mathrm{l}$. The explanation for this discrepancy is unclear. It cannot be ruled out that oscillating factors other than ATP affect $\mathrm{K}_{\mathrm{ATP}}$ channel conductance, or that ATP oscillations occur in microcompartments unavailable to the biosensor. Our observation that oscillations primarily occurred at high glucose concentrations (Fig. 3) is consistent with modelling data, indicating that the glucokinase reaction needs to exceed a minimal rate for oscillations occur [41].

Crosstalk between ATP and $\mathrm{Ca}^{2+}$ occurs at different levels. First, a rise of the ATP:ADP ratio causes closure of $\mathrm{K}_{\mathrm{ATP}}$ channels and membrane depolarisation, resulting in opening of voltage-gated $\mathrm{Ca}^{2+}$ channels [3]. Our simultaneous recordings of $[\mathrm{ATP}]_{\mathrm{pm}}$ and $\left[\mathrm{Ca}^{2+}\right]_{\mathrm{pm}}$ in beta cells (Fig. 5) show that the initial rise of $[\mathrm{ATP}]_{\mathrm{pm}}$ coincides with the characteristic transient lowering of $\left[\mathrm{Ca}^{2+}\right]_{\mathrm{pm}}$, which is known to reflect $\mathrm{Ca}^{2+}$ sequestration into intracellular stores after energising the sarco(endo)plasmic reticulum $\mathrm{Ca}^{2+}$ ATPases [42-44]. Indeed, the half-maximal effect of glucose on ATP elevation at $5.2 \mathrm{mmol} / \mathrm{l}$ is almost identical to the $5.5 \mathrm{mmol} / 1$ reported for $\mathrm{Ca}^{2+}$ sequestration into the endoplasmic reticulum [43]. The subsequent rise of $\left[\mathrm{Ca}^{2+}\right]_{\mathrm{pm}}$, reflecting voltage-dependent $\mathrm{Ca}^{2+}$ entry, coincided with a transient interruption of the $[\mathrm{ATP}]_{\mathrm{pm}}$ increase or even a small lowering, before the concentration continued to increase at a slower rate. During the following oscillations there was a clear anti-phasic relationship between $\left[\mathrm{Ca}^{2+}\right]_{\mathrm{pm}}$ and $[\mathrm{ATP}]_{\mathrm{pm}}$. An additional indication that there is an inverse coupling between the messengers derives from the findings: (1) that $\left[\mathrm{Ca}^{2+}\right]_{\mathrm{pm}}$ elevation in response to $\mathrm{KCl}$ depolarisation caused a lowering of $[\mathrm{ATP}]_{\mathrm{pm}}$ irrespective of the ambient glucose concentration; and (2) that the glucose-induced $[\mathrm{ATP}]_{\mathrm{pm}}$ elevation was further increased when $\left[\mathrm{Ca}^{2+}\right]_{\mathrm{pm}}$ was lowered by preventing influx through the voltage-dependent $\mathrm{Ca}^{2+}$ channels. In contrast, previous studies of insulinoma cells, as well as mouse and human beta cells, have instead associated glucose- and depolarisation-induced rises of $\left[\mathrm{Ca}^{2+}\right]_{\mathrm{i}}$ with increased levels of cytoplasmic ATP [24, 25]. In a recent study with Perceval, the biphasic cytoplasmic ATP elevation in response to glucose was interpreted as an initial $\mathrm{Ca}^{2+}$-independent ATP production, followed by a further rise due to $\mathrm{Ca}^{2+}$ activation of mitochondrial metabolism [33], mirroring previous data from luciferase-expressing INS$1 \mathrm{E}$ cells [26]. This conclusion is not supported by the present observation, since the glucose-induced elevation of $[\mathrm{ATP}]_{\mathrm{pm}}$ was not reduced when cytoplasmic $\mathrm{Ca}^{2+}$ entry was prevented (Fig. 4). However, $\mathrm{Ca}^{2+}$ seems to be required to prevent a gradual time-dependent lowering of $[\mathrm{ATP}]_{\mathrm{pm}}$, consistent with 
the concept that $\mathrm{Ca}^{2+}$-activated mitochondrial metabolism is important for sustained insulin secretion [26].

Despite ample evidence of metabolic oscillations in beta cells, their origin remains obscure. It has been suggested that metabolic oscillations are determined by oscillatory glycolysis due to the presence of the muscle isoform of phosphofructokinase, which is positively regulated by its product, fructose-bisphosphate [45, 46], and inhibited by high levels of ATP [47]. This model, which predicts that metabolic oscillations can occur independently of $\mathrm{Ca}^{2+}$ variations, is supported by work showing the maintenance of glucosestimulated NAD $(\mathrm{P}) \mathrm{H}$ oscillations under different conditions associated with stable $\left[\mathrm{Ca}^{2+}\right]_{\mathrm{i}}$ elevation in mouse islets [47]. Metabolic oscillations may also arise from the effect of $\mathrm{Ca}^{2+}$ feedback on ATP production [19, 20, 28-32] or consumption [27], and consequently occur exclusively in the presence of $\left[\mathrm{Ca}^{2+}\right]_{i}$ oscillations. Our present data support a critical negative feedback role of $\mathrm{Ca}^{2+}$ in the generation of metabolic oscillations, but it is not known at which level $\mathrm{Ca}^{2+}$ exerts its effect. It has been shown that $\left[\mathrm{Ca}^{2+}\right]_{\mathrm{i}}$ oscillations in beta cells are accompanied by periodic depolarisations of the mitochondrial inner membrane [19, 20]. However, a more recent study indicated that glucoseand pyruvate-induced oscillations of the plasma membrane potential and $\left[\mathrm{Ca}^{2+}\right]_{\mathrm{i}}$ in INS-1 beta cells occur without significant alterations of the mitochondrial membrane potential [48]. ATP oscillations may therefore arise from variations in $\mathrm{Ca}^{2+}$-induced ATP consumption rather than production. The Henquin laboratory [27] has demonstrated that $\mathrm{Ca}^{2+}$-mediated reduction of the ATP:ADP ratio in beta cells essentially reflects increased activity of ATP-dependent ion transporters and not energy requirements of the secretory process. Although $\mathrm{Ca}^{2+}$ has effects at many levels, our findings are entirely consistent with the concept that increased ATP consumption by $\mathrm{Ca}^{2+}$ extrusion dominates in the sub-membrane space.

The present study is the first analysis of the dynamic relationship between $\mathrm{Ca}^{2+}$ and ATP in the beta cell subplasma membrane space, where exocytosis of insulin occurs. Glucose induces pronounced oscillations of $[\mathrm{ATP}]_{\mathrm{pm}}$ and $\left[\mathrm{Ca}^{2+}\right]_{\mathrm{pm}}$, with each $\mathrm{Ca}^{2+}$ increase corresponding to a reduction of ATP. The bidirectional interplay between the messengers is central to the generation of metabolic and ionic oscillations underlying pulsatile insulin secretion.

Acknowledgements We thank G. Yellen (Harvard Medical School) for the kind gift of Perceval cDNA and A. Wuttke (Uppsala University) for assistance with the cross-correlation analysis. Human pancreatic islets were obtained from the Nordic Network for Clinical Islet Transplantation, headed by O. Korsgren, and supported by the Swedish national strategic research initiative, Excellence of Diabetes Research in Sweden, and by the Juvenile Diabetes Research Foundation (312008-413 European Consortium for Islet Transplantation Islets for basic research programme).
Funding This work was supported by grants from the Swedish Research Council, the Swedish Diabetes Association, the NovoNordisk Foundation, the EFSD/Merck Sharp \& Dohme and the Family Ernfors Foundation.

Duality of interest The authors state that there is no duality of interest associated with this manuscript.

Contribution statement JL and HYS researched and analysed the data and critically revised the manuscript. EG contributed to the analysis and interpretation of data, and critically revised the manuscript. AT conceived the study, contributed to the analysis and interpretation of data, and wrote the article. All authors approved the final version to be published.

Open Access This article is distributed under the terms of the Creative Commons Attribution Noncommercial License which permits any noncommercial use, distribution, and reproduction in any medium, provided the original author(s) and the source are credited.

\section{References}

1. Newgard CB, McGarry JD (1995) Metabolic coupling factors in pancreatic $\beta$-cell signal transduction. Annu Rev Biochem 64:689719

2. Maechler P, Wollheim CB (2001) Mitochondrial function in normal and diabetic $\beta$-cells. Nature 414:807-812

3. Ashcroft FM, Rorsman P (1989) Electrophysiology of the pancreatic $\beta$-cell. Prog Biophys Mol Biol 54:87-143

4. Takahashi N, Kadowaki T, Yazaki Y, Ellis-Davies GC, Miyashita Y, Kasai H (1999) Post-priming actions of ATP on $\mathrm{Ca}^{2+}$-dependent exocytosis in pancreatic beta cells. Proc Natl Acad Sci U S A 96:760-765

5. Bratanova-Tochkova TK, Cheng H, Daniel S et al (2002) Triggering and augmentation mechanisms, granule pools, and biphasic insulin secretion. Diabetes 51(Suppl 1):S83-S90

6. Henquin JC (2009) Regulation of insulin secretion: a matter of phase control and amplitude modulation. Diabetologia 52:739-751

7. Gilon P, Shepherd RM, Henquin JC (1993) Oscillations of secretion driven by oscillations of cytoplasmic $\mathrm{Ca}^{2+}$ as evidences in single pancreatic islets. J Biol Chem 268:22265-22268

8. Bergsten P, Grapengiesser E, Gylfe E, Tengholm A, Hellman B (1994) Synchronous oscillations of cytoplasmic $\mathrm{Ca}^{2+}$ and insulin release in glucose-stimulated pancreatic islets. J Biol Chem 269:8749-8753

9. Dyachok O, Idevall-Hagren O, Sågetorp J et al (2008) Glucoseinduced cyclic AMP oscillations regulate pulsatile insulin secretion. Cell Metabol 8:26-37

10. Tengholm A, Gylfe E (2009) Oscillatory control of insulin secretion. Mol Cell Endocrinol 297:58-72

11. Tian G, Sandler S, Gylfe E, Tengholm A (2011) Glucose- and hormone-induced cAMP oscillations in $\alpha$ - and $\beta$-cells within intact pancreatic islets. Diabetes 60:1535-1543

12. Longo EA, Tornheim K, Deeney JT et al (1991) Oscillations in cytosolic free $\mathrm{Ca}^{2+}$, oxygen consumption, and insulin secretion in glucose-stimulated rat pancreatic islets. J Biol Chem 266:93149319

13. Jung SK, Aspinwall CA, Kennedy RT (1999) Detection of multiple patterns of oscillatory oxygen consumption in single mouse islets of Langerhans. Biochem Biophys Res Commun 259:331335 
14. Ortsäter H, Liss P, Lund PE, Åkerman KE, Bergsten P (2000) Oscillations in oxygen tension and insulin release of individual pancreatic ob/ob mouse islets. Diabetologia 43:1313-1318

15. Jung SK, Kauri LM, Qian WJ, Kennedy RT (2000) Correlated oscillations in glucose consumption, oxygen consumption, and intracellular free $\mathrm{Ca}^{2+}$ in single islets of Langerhans. J Biol Chem 275:6642-6650

16. Dahlgren GM, Kauri LM, Kennedy RT (2005) Substrate effects on oscillations in metabolism, calcium and secretion in single mouse islets of Langerhans. Biochim Biophys Acta 1724:23-36

17. Chou HF, Berman N, Ipp E (1992) Oscillations of lactate released from islets of Langerhans: evidence for oscillatory glycolysis in $\beta$ cells. Am J Physiol 262:E800-E805

18. Luciani DS, Misler S, Polonsky KS (2006) $\mathrm{Ca}^{2+}$ controls slow $\mathrm{NAD}(\mathrm{P}) \mathrm{H}$ oscillations in glucose-stimulated mouse pancreatic islets. J Physiol 572:379-392

19. Krippeit-Drews P, Dufer M, Drews G (2000) Parallel oscillations of intracellular calcium activity and mitochondrial membrane potential in mouse pancreatic B-cells. Biochem Biophys Res Commun 267:179-183

20. Kindmark H, Köhler M, Brown G, Bränstrom R, Larsson O, Berggren PO (2001) Glucose-induced oscillations in cytoplasmic free $\mathrm{Ca}^{2+}$ concentration precede oscillations in mitochondrial membrane potential in the pancreatic $\beta$-cell. J Biol Chem 276:34530-34536

21. Nilsson T, Schultz V, Berggren PO, Corkey BE, Tornheim K (1996) Temporal patterns of changes in ATP/ADP ratio, glucose 6-phosphate and cytoplasmic free $\mathrm{Ca}^{2+}$ in glucose-stimulated pancreatic beta-cells. Biochem J 314(Pt 1):91-94

22. Köhler M, Norgren S, Berggren PO et al (1998) Changes in cytoplasmic ATP concentration parallels changes in ATPregulated $\mathrm{K}^{+}$-channel activity in insulin-secreting cells. FEBS Lett 441:97-102

23. Maechler P, Wang H, Wollheim CB (1998) Continuous monitoring of ATP levels in living insulin secreting cells expressing cytosolic firefly luciferase. FEBS Lett 422:328-332

24. Kennedy HJ, Pouli AE, Ainscow EK, Jouaville LS, Rizzuto R, Rutter GA (1999) Glucose generates sub-plasma membrane ATP microdomains in single islet $\beta$-cells. Potential role for strategically located mitochondria. J Biol Chem 274:13281-13291

25. Ainscow EK, Rutter GA (2002) Glucose-stimulated oscillations in free cytosolic ATP concentration imaged in single islet beta-cells: evidence for a $\mathrm{Ca}^{2+}$-dependent mechanism. Diabetes 51(Suppl 1): S162-S170

26. Wiederkehr A, Szanda G, Akhmedov D et al (2011) Mitochondrial matrix calcium is an activating signal for hormone secretion. Cell Metabol 13:601-611

27. Detimary P, Gilon P, Henquin JC (1998) Interplay between cytoplasmic $\mathrm{Ca}^{2+}$ and the ATP/ADP ratio: a feedback control mechanism in mouse pancreatic islets. Biochem J 333:269-274

28. Magnus G, Keizer J (1998) Model of $\beta$-cell mitochondrial calcium handling and electrical activity. I. Cytoplasmic variables. Am J Physiol 274:C1158-C1173

29. McCormack JG, Longo EA, Corkey BE (1990) Glucose-induced activation of pyruvate dehydrogenase in isolated rat pancreatic islets. Biochem J 267:527-530

30. Pralong WF, Spät A, Wollheim CB (1994) Dynamic pacing of cell metabolism by intracellular $\mathrm{Ca}^{2+}$ transients. J Biol Chem 269:27310-27314
31. Civelek VN, Deeney JT, Shalosky NJ et al (1996) Regulation of pancreatic $\beta$-cell mitochondrial metabolism: influence of $\mathrm{Ca}^{2+}$, substrate and ADP. Biochem J 318(Pt 2):615-621

32. Pitter JG, Maechler P, Wollheim CB, Spat A (2002) Mitochondria respond to $\mathrm{Ca}^{2+}$ already in the submicromolar range: correlation with redox state. Cell Calcium 31:97-104

33. Tarasov AI, Semplici F, Ravier MA et al (2012) The mitochondrial $\mathrm{Ca}^{2+}$ uniporter MCU is essential for glucose-induced ATP increases in pancreatic $\beta$-cells. PLoS One 7:e39722

34. Berg J, Hung YP, Yellen G (2009) A genetically encoded fluorescent reporter of ATP:ADP ratio. Nat Meth 6:161-166

35. Miyazaki J, Araki K, Yamato E et al (1990) Establishment of a pancreatic $\beta$ cell line that retains glucose-inducible insulin secretion: special reference to expression of glucose transporter isoforms. Endocrinology 127:126-132

36. Thore S, Wuttke A, Tengholm A (2007) Rapid turnover of phosphatidylinositol-4,5-bisphosphate in insulin-secreting cells mediated by $\mathrm{Ca}^{2+}$ and the ATP-to-ADP ratio. Diabetes 56:818-826

37. Schulze DU, Dufer M, Wieringa B, Krippeit-Drews P, Drews G (2007) An adenylate kinase is involved in $\mathrm{K}_{\mathrm{ATP}}$ channel regulation of mouse pancreatic beta cells. Diabetologia 50:2126-2134

38. Gribble FM, Loussouarn G, Tucker SJ, Zhao C, Nichols CG, Ashcroft FM (2000) A novel method for measurement of submembrane ATP concentration. J Biol Chem 275:30046-30049

39. Westerlund J, Hellman B, Bergsten P (1996) Pulsatile insulin release from mouse islets occurs in the absence of stimulated entry of $\mathrm{Ca}^{2+}$. J Clin Invest 97:1860-1863

40. Dryselius S, Lund PE, Gylfe E, Hellman B (1994) Variations in ATP-sensitive $\mathrm{K}^{+}$channel activity provide evidence for inherent metabolic oscillations in pancreatic $\beta$-cells. Biochem Biophys Res Commun 205:880-885

41. Nunemaker CS, Bertram R, Sherman A, Tsaneva-Atanasova K, Daniel CR, Satin LS (2006) Glucose modulates $\left[\mathrm{Ca}^{2+}\right]_{\mathrm{i}}$ oscillations in pancreatic islets via ionic and glycolytic mechanisms. Biophys J 91:2082-2096

42. Chow RH, Lund PE, Löser S, Panten U, Gylfe E (1995) Coincidence of early glucose-induced depolarization with lowering of cytoplasmic $\mathrm{Ca}^{2+}$ in mouse pancreatic $\beta$-cells. J Physiol 485(Pt 3):607-617

43. Tengholm A, Hellman B, Gylfe E (1999) Glucose regulation of free $\mathrm{Ca}^{2+}$ in the endoplasmic reticulum of mouse pancreatic beta cells. J Biol Chem 274:36883-36890

44. Arredouani A, Henquin JC, Gilon P (2002) Contribution of the endoplasmic reticulum to the glucose-induced $\left[\mathrm{Ca}^{2+}\right]_{\mathrm{c}}$ response in mouse pancreatic islets. Am J Physiol Endocrinol Metab 282: E982-E991

45. Tornheim K (1997) Are metabolic oscillations responsible for normal oscillatory insulin secretion? Diabetes 46:1375-1380

46. Merrins MJ, Bertram R, Sherman A, Satin LS (2012) Phosphofructo2-kinase/fructose-2,6-bisphosphatase modulates oscillations of pancreatic islet metabolism. PLoS One 7:e34036

47. Merrins MJ, Fendler B, Zhang M, Sherman A, Bertram R, Satin LS (2010) Metabolic oscillations in pancreatic islets depend on the intracellular $\mathrm{Ca}^{2+}$ level but not $\mathrm{Ca}^{2+}$ oscillations. Biophys J 99:76-84

48. Goehring I, Gerencser AA, Schmidt S, Brand MD, Mulder H, Nicholls DG (2012) Plasma membrane potential oscillations in insulin secreting Ins-1 832/13 cells do not require glycolysis and are not initiated by fluctuations in mitochondrial bioenergetics. J Biol Chem 287:15706-15717 